\title{
Serum androgen-anabolic hormones and the risk of rheumatoid arthritis
}

\author{
R Heikkilä, K Aho, M Heliövaara, P Knekt, A Reunanen, A Aromaa, A Leino, T Palosuo
}

\begin{abstract}
Objective-It has been hypothesised, mainly on the basis of indirect evidence, that low serum concentrations of androgen-anabolic hormones would play a causal part in the aetiology of rheumatoid arthritis (RA).

Methods-A case-control study was nested with a Finnish cohort of 19072 adults who had neither arthritis nor a history of it at the baseline examination during 1973-1977. Pre-illness serum specimens for the assay of testosterone and dehydroepiandrosterone sulphate (DHEAS) were available from 116 cases who had developed RA by late 1989 . Three controls per each incident case were individually matched for sex, age, and municipality.

Results-The mean testosterone concentration was $1.4 \mathrm{nmol} / 1$ in those 84 women who developed RA and $1.4 \mathrm{nmol} / 1$ in their controls; the corresponding figures for DHEAS were $5.2 \mu \mathrm{mol} / 1$ and $5.5 \mu \mathrm{mol} / 1$, respectively. Mean testosterone concentration in the 32 male cases was 26.1 $\mathrm{nmol} / 1$ and $26.4 \mathrm{nmol} / 1$ in their controls; the corresponding figures for DHEAS were $11.2 \mu \mathrm{mol} / 1$ and $10.1 \mu \mathrm{mol} / 1$, respectively. Analysis by subgroups (rheumatoid factor positive and negative disease, premenopausal and postmenopausal women) and by hormone distributions showed no differences.
\end{abstract}

Conclusion-The findings are not in line with the contention that low concentrations of testosterone and DHEAS play a part in the aetiology of RA.

(Ann Rheum Dis 1998;57:281-285)

Hämeenlinna, Finland

R Heikkilä

National Public Health Institute, Helsinki,

Finland

K Aho

M Heliövaara

P Knekt

A Reunanen

A Aromaa

T Palosuo

Research and

Development Centre,

Social Insurance

Institution, Turku,

Finland

A Leino

Correspondence to:

Dr R Heikkilä, Kanta-Häme

Central Hospital, Fin-13530,

Hämeenlinna, Finland.

Accepted for publication 17 March 1998 major secretory products of the adrenal gland, but their functions are, as yet, largely unknown.
In women DHEA acts as a weak androgen, whereas in men it may have oestrogen-like effects. ${ }^{6}$

No significant differences between RA patients and controls have been observed in the values of estradiol. ${ }^{7} \mathrm{~A}$ consensus exists that lower concentrations of testosterone occur in men with $\mathrm{RA}^{8-11}$; the same may hold for DHEAS,${ }^{8} 9$ although one study failed to show any difference. ${ }^{12}$ In women the findings have been controversial. ${ }^{13-20}$ The reasons for this may in part be dependent on the selection of controls: healthy volunteers compared with patients with osteoarthrosis. ${ }^{21}$

Yet the problem remains of whether the observed dysfunctions or deficiencies of androgen-anabolic hormones in RA may be playing a causal part or are only secondary to the disease. ${ }^{7}$ Some evidence is available that the difference can be explained at least partially by disease activity. ${ }^{22}$ On the other hand, associations have been reported between HLA and both susceptibility to RA and low testosterone concentrations. ${ }^{23}{ }^{24}$ According to a preliminary report, low DHEAS concentrations in premenopausal women were found to precede clinically manifest RA. ${ }^{25}$ We here approach the issue on the basis of a larger series of pre-RA specimens from both men and women.

\section{Methods}

During 1973-1977, the Social Insurance Institution's Mobile Clinic Unit undertook multiphasic health examinations in 12 municipalities in four regions of Finland, in which the main emphasis was on the risk factors for cardiovascular disorders. In each of the four geographical regions, all inhabitants or a random sample of inhabitants of one rural municipality and one urban or semiurban municipality as well as the employees of one factory were invited to attend the examination. A total of 19518 subjects who were 20 years of age or older ( $83 \%$ of those invited) participated in the examinations. The mean age of the subjects was 45 years (age range 20-98).

The population at risk (19 072 subjects) consisted of participants who had no previous history of arthritis or other rheumatic disease, according to the Social Insurance Institution's population register or to a questionnaire administered at the baseline examinations. ${ }^{26}$ Morbidity and mortality of all examinees were followed up continuously. Participants in the survey who later developed chronic arthritis were identified by linking the survey data with the Social Insurance Institution's population register up to the end of 1989 , using the unique social security code assigned to each Finnish 
Table 1 Mean concentrations of serum testosterone (nmol/l) and dihydroepiandrosterone sulphate (DHEAS, $\mu m o l / l)$ in incident cases with RF positive $R A, R F$ negative $R A$, and their matched controls

\begin{tabular}{|c|c|c|c|c|c|c|c|c|c|c|c|c|}
\hline \multirow{2}{*}{$\begin{array}{l}\text { Population group } \\
\text { Sex hormone }\end{array}$} & \multicolumn{4}{|c|}{$R F$ positive $R A$} & \multicolumn{4}{|c|}{$R F$ negative $R A$} & \multicolumn{4}{|l|}{$R A$ in total } \\
\hline & No of sets & Cases & Controls & $p$ Value & No of sets & Cases & Controls & $p$ Value & No of sets & Cases & Controls & $p$ Value \\
\hline \multicolumn{13}{|l|}{ All men } \\
\hline Testosterone & 27 & 25.6 & 26.4 & 0.75 & 5 & 28.4 & 26.2 & 0.42 & 32 & 26.1 & 26.4 & 0.88 \\
\hline DHEAS & 27 & 11.5 & 10.2 & 0.24 & 5 & 9.6 & 9.3 & 0.94 & 32 & 11.2 & 10.1 & 0.28 \\
\hline \multicolumn{13}{|l|}{ All women } \\
\hline Testosterone & 57 & 1.4 & 1.4 & 0.94 & 27 & 1.4 & 1.3 & 0.94 & 84 & 1.4 & 1.4 & 0.91 \\
\hline DHEAS & 57 & 5.5 & 5.5 & 0.86 & 27 & 4.7 & 5.3 & 0.41 & 84 & 5.2 & 5.5 & 0.50 \\
\hline \multicolumn{13}{|c|}{ Women aged $<50$ at the onset of RA } \\
\hline Testosterone & 18 & 1.3 & 1.5 & 0.22 & 9 & 1.3 & 1.4 & 0.58 & 27 & 1.3 & 1.5 & 0.17 \\
\hline DHEAS & 18 & 7.8 & 8.2 & 0.74 & 9 & 5.3 & 5.4 & 0.90 & 27 & 7.0 & 7.3 & 0.72 \\
\hline \multicolumn{13}{|c|}{ Women aged $<50$ at entry but $\geqslant 50$ at the onset of RA } \\
\hline Testosterone & 16 & 1.5 & 1.4 & 0.85 & 9 & 1.5 & 1.6 & 0.68 & 25 & 1.5 & 1.5 & 0.91 \\
\hline DHEAS & 16 & 6.0 & 5.1 & 0.10 & 9 & 5.2 & 6.1 & 0.63 & 25 & 5.7 & 5.5 & 0.74 \\
\hline \multicolumn{13}{|c|}{ Women aged $\geqslant 50$ at entry } \\
\hline Testosterone & 23 & 1.5 & 1.3 & 0.49 & 9 & 1.3 & 1.1 & 0.27 & 32 & 1.4 & 1.2 & 0.26 \\
\hline DHEAS & 23 & 3.2 & 3.7 & 0.30 & 9 & 3.6 & 4.3 & 0.10 & 32 & 3.3 & 3.9 & 0.13 \\
\hline
\end{tabular}

citizen. In Finland reimbursed drugs are provided for certain chronic diseases, including chronic inflammatory rheumatic diseases. Eligibility requires a comprehensive medical certificate written by the attending physician. These written documents were carefully reviewed to identify incident cases of RA. Sufficient information concerning diagnosis, onset of disease, and rheumatoid factor (RF) status was obtained on 124 cases. ${ }^{26}$ Serum for the purposes of study described here was available from 116 of these subjects. Three controls per case were selected by individual matching, using sex, municipality, and age as matching factors. In some instances serum from only two controls was available; thus the total number of controls was 329. Matching for municipality also controlled for both the time of baseline examination and for the duration of serum sample storage.

Serum samples were drawn and kept frozen at $-20^{\circ} \mathrm{C}$ until thawed in 1994 . Serum testosterone and DHEAS concentrations were quantified by commercial radioimmunoassay kits from Diagnostic Products Corporation, Los Angeles, CA, USA. The interassay coefficient of variation for testosterone was $6.9 \%$ for the low level controls, $4.2 \%$ for the median level controls and $6.4 \%$ for the high level controls. The corresponding figures for DHEAS were $13.6 \%, 8.6 \%$, and $5.5 \%$. The median testosterone concentration for both men and women and DHEAS concentration for women fell in the middle of the normal range used by the laboratory. DHEAS reference values were not available for men.

Table 2 Relative odds, with 95\% confidence intervals, of $R F$ positive $R A, R F$ negative $R A$, and $R A$ in total between quintiles ${ }^{\star}$ of serum testosterone and DHEAS concentrations in men and women

\begin{tabular}{|c|c|c|c|c|c|c|c|c|c|c|c|c|}
\hline \multirow{2}{*}{$\begin{array}{l}\text { Sex } \\
\text { Quintiles }\end{array}$} & \multicolumn{4}{|c|}{$R F$ positive } & \multicolumn{4}{|c|}{$R F$ negative $R A$} & \multicolumn{4}{|c|}{$R A$ in total } \\
\hline & $\begin{array}{l}\text { No of } \\
\text { cases }\end{array}$ & $\begin{array}{l}\text { No of } \\
\text { controls }\end{array}$ & $\begin{array}{l}\text { Odds } \\
\text { ratio }\end{array}$ & $95 \% C I$ & $\begin{array}{l}\text { No of } \\
\text { cases }\end{array}$ & $\begin{array}{l}\text { No of } \\
\text { controls }\end{array}$ & $\begin{array}{l}\text { Odds } \\
\text { ratio }\end{array}$ & $95 \% C 9 I$ & $\begin{array}{l}\text { No of } \\
\text { cases }\end{array}$ & $\begin{array}{l}\text { No of } \\
\text { controls }\end{array}$ & $\begin{array}{l}\text { Odds } \\
\text { ratio }\end{array}$ & $95 \% C I$ \\
\hline \multicolumn{13}{|l|}{ Men } \\
\hline \multicolumn{13}{|l|}{ Testosterone } \\
\hline I (Lowest) & 3 & 13 & 1.00 & & 0 & 5 & \multirow{2}{*}{\multicolumn{2}{|c|}{ The model for }} & 3 & 18 & 1.00 & \\
\hline II & 9 & 17 & 2.59 & $0.53,12.54$ & 2 & 0 & & & 11 & 17 & 4.36 & $0.98,19.45$ \\
\hline III & 7 & 17 & 2.05 & $0.43,9.79$ & 1 & 0 & & 8 & 17 & 3.42 & $0.76,15.41$ \\
\hline IV & 4 & 14 & 1.26 & $0.25,6.46$ & 0 & 2 & \multicolumn{2}{|c|}{ converge } & 4 & 16 & 1.57 & $0.32,7.81$ \\
\hline V (Highest) & 4 & 14 & 1.27 & $0.23,7.06$ & 2 & 5 & \multirow{2}{*}{\multicolumn{2}{|c|}{0.78}} & 6 & 19 & 1.91 & $0.39,9.40$ \\
\hline $\mathrm{p}$ for trend & & & 0.92 & & & & & & & & 0.99 & \\
\hline \multicolumn{13}{|l|}{ DHEAS } \\
\hline I (Lowest) & 4 & 11 & 1.00 & & 1 & 6 & \multicolumn{2}{|c|}{ The model for } & 5 & 17 & 1.00 & \\
\hline II & 4 & 17 & 0.80 & $0.17,3.86$ & 1 & 1 & \multicolumn{2}{|c|}{ quintiles did not } & 5 & 18 & 1.14 & $0.29,4.55$ \\
\hline III & 2 & 15 & 0.47 & $0.07,3.29$ & 0 & 2 & \multicolumn{2}{|c|}{ converge } & 2 & 17 & 0.53 & $0.08,3.39$ \\
\hline IV & 9 & 18 & 1.55 & $0.32,7.48$ & 2 & 0 & & & 11 & 18 & 2.31 & $0.57,9.26$ \\
\hline V (Highest) & 8 & 14 & 2.03 & $0.40,10.46$ & 1 & 3 & \multirow{2}{*}{\multicolumn{2}{|c|}{0.93}} & 9 & 17 & 2.30 & $0.54,9.72$ \\
\hline $\mathrm{p}$ for trend & & & 0.24 & & & & & & & & 0.42 & \\
\hline \multicolumn{13}{|l|}{ Women } \\
\hline \multicolumn{13}{|l|}{ Testosterone } \\
\hline I (Lowest) & 10 & 29 & 1.00 & & 4 & 17 & \multicolumn{2}{|l|}{1.00} & 14 & 46 & 1.00 & \\
\hline II & 12 & 34 & 1.06 & $0.39,2.86$ & 7 & 17 & 1.92 & $0.42,8.78$ & 19 & 51 & 1.28 & $0.56,2.94$ \\
\hline III & 11 & 34 & 0.91 & $0.33,2.53$ & 5 & 14 & 1.46 & $0.32,6.61$ & 16 & 48 & 1.07 & $0.46,2.49$ \\
\hline IV & 11 & 31 & 1.05 & $0.40,2.76$ & 6 & 17 & 1.42 & $0.32,6.39$ & 17 & 48 & 1.15 & $0.51,2.61$ \\
\hline V (Highest) & 13 & 37 & 1.02 & $0.36,2.92$ & 5 & 12 & 1.69 & $0.37,7.63$ & 18 & 49 & 1.21 & $0.51,2.86$ \\
\hline $\mathrm{p}$ for trend & & & 0.88 & & & & 0.82 & & & & 0.80 & \\
\hline \multicolumn{13}{|l|}{ DHEAS } \\
\hline I (Lowest) & 16 & 35 & 1.00 & & 4 & 13 & \multicolumn{2}{|l|}{1.00} & 20 & 48 & 1.00 & \\
\hline II & 7 & 31 & 0.47 & $0.17,1.32$ & 9 & 18 & 1.98 & $0.51,7.69$ & 16 & 49 & 0.78 & $0.36,1.69$ \\
\hline III & 5 & 33 & 0.30 & $0.09,1.00$ & 9 & 16 & 1.92 & $0.50,7.32$ & 14 & 49 & 0.67 & $0.29,1.54$ \\
\hline IV & 15 & 32 & 1.01 & $0.37,2.73$ & 2 & 16 & 0.40 & $0.07,2.36$ & 17 & 48 & 0.80 & $0.36,1.79$ \\
\hline V (Highest) & 14 & 34 & 0.96 & $0.31,2.92$ & 3 & 14 & 0.64 & $0.12,3.41$ & 17 & 48 & 0.82 & $0.34,1.95$ \\
\hline $\mathrm{p}$ for trend & & & 0.88 & & & & 0.36 & & & & 0.54 & \\
\hline
\end{tabular}

* The quintiles are based on the distributions of concentrations among controls. Quintile divisions are, for testosterone (nmol/1) $<18.61,18.61-23.43,23.44-28.31$, $28.32-32.13,>32.14$ among men and $<0.81,0.81-1.15,1.16-1.45,1.46-1.86,>1.86$ among women, for DHEAS $(\mu$ mol/1) $<5.98,5.99-8.27,8.28-10.27,10.28-$ $13.73,>13.73$ among men and $<2.80,2.80-4.04,4.05-5.41,5.42-7.45,>7.45$ among women. 

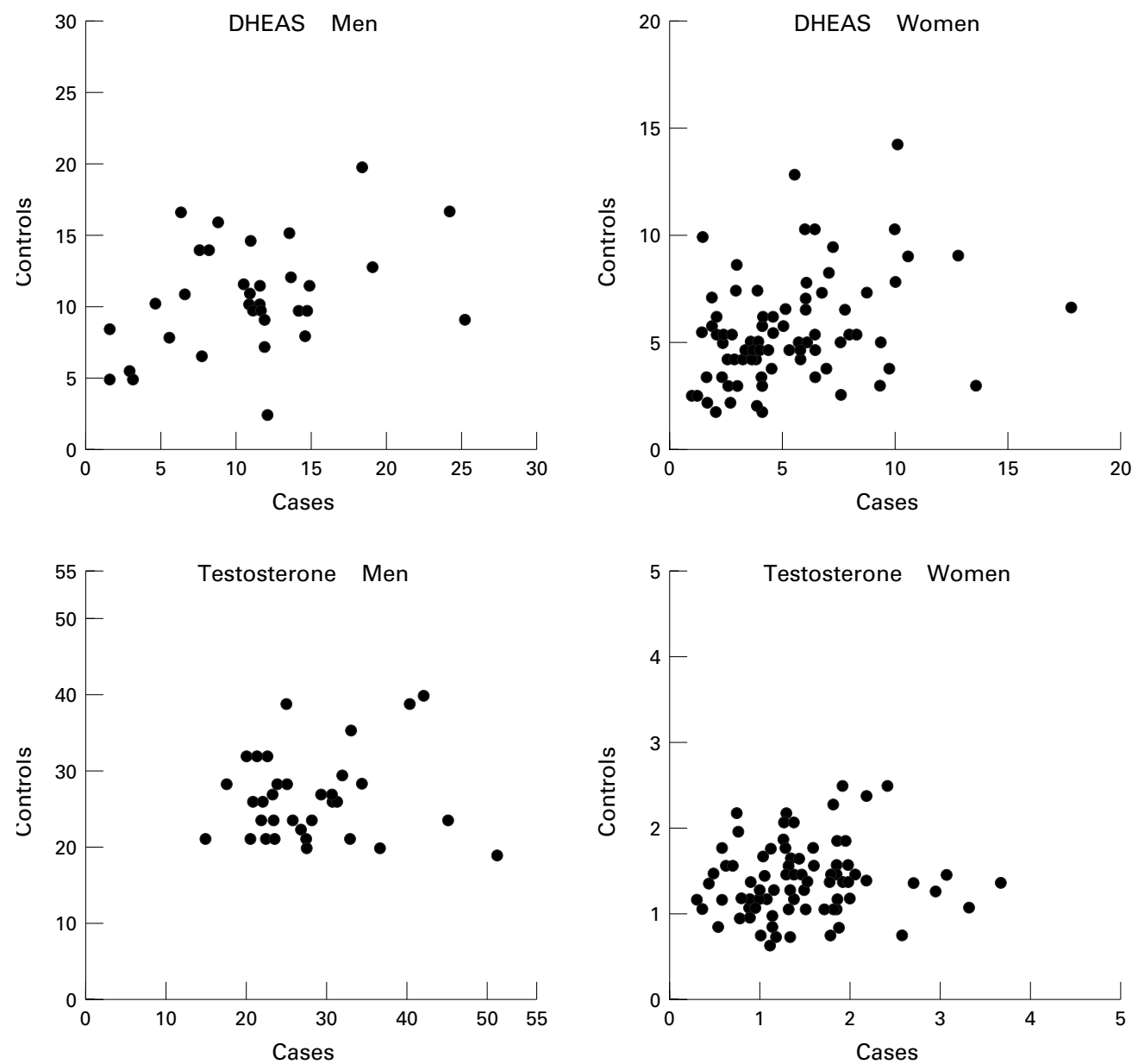

Figure 1 Testosterone and dehydroepiandrosterone sulphate (DHEAS) concentrations in cases and in controls. Each dot represents one case and the mean of the set of matched controls.

Significance of the differences in mean concentrations of serum testosterone and DHEAS between RA cases and their matched controls was tested by the paired $t$ test. The conditional logistic model $^{27}$ was used to estimate the associations between serum hormone concentrations and RA risk. Relative odds with 95\% confidence intervals were computed for quintiles of serum testosterone and DHEAS concentrations. The quintile limits were based on hormone distributions among controls. To test linear trends, serum testosterone and DHEAS were also entered as continuous variables into the models. Likelihood ratio tests were computed on the basis of these models.

\section{Results}

No differences were noted in the concentrations of serum testosterone or DHEAS between the cases who developed RA and their controls either men or women (fig 1). No significant associations between the hormones and RA risk were found even when RF positive and RF negative RA and the age groups of women were analysed separately (table 1 ), or when the relative risks were estimated for quintiles of serum testosterone and DHEAS (table 2). Furthermore, there were no significant clusters in the distributions of hormone concentrations in women of different age groups (data not shown).
Data analysis was also stratified by time span of $<5$ years and $\geqslant 5$ years from baseline examination until the development of RA. No differences were found in serum testosterone or DHEAS between the incident cases with RA and their controls (data not shown).

\section{Discussion}

Over the past 10 years, considerable interest has been devoted towards measuring levels of circulating steroid hormones in epidemiological studies. Much research has been undertaken in view of the possibility that certain hormone profiles may predispose people to the development of illnesses such as coronary heart disease and cancer. ${ }^{28-30}$ Nearly all the studies were based on serum specimens stored for long periods. Findings have been contradictory, with some studies showing significant differences between cases and controls and several others failing to do so.

For the purpose of the work described here, we chose to study testosterone and DHEAS. In men, testosterone is the predominant steroid hormone produced by the Leydig cells of the testes. About half the testosterone production in adult women is normally derived from peripheral tissue conversion of its adrenal precursors and the other half is synthesised in the ovaries and in the adrenal. DHEA is secreted almost entirely by the adrenal after which it is 
sulphated in the liver to become hormonally inactive DHEAS. It is the most abundant steroid in the serum of adults, both men and nonpregnant women. Because of its long half life and high concentrations, DHEAS does not show a discernible diurnal variation and is a good marker of adrenal androgen production, at least in women.

No difference emerged in the hormone concentrations between our cases and controls. These findings were consistent between men and women and other subgroups of the study population. As we did not measure the sex hormone binding globulin, there remains the possibility that there could have been some difference in the free testosterone concentrations. The total number of cases was sufficiently large to exclude the possibility of $\beta$ error resulting from a small number of cases. It is, however, appropriate to deal with RF positive and RF negative cases separately. RF positive RA may represent a single disease entity, whereas $R F$ negative RA is almost certainly a heterogeneous mixture of disease conditions. For instance, a collaborative Finnish-Russian study of patients from Heinola (Finland) and Moscow provided evidence that RF negative RA as seen in the above two centres differed in clinical and immunogenetic characteristics. ${ }^{31}$

In studies of sex hormones, men and women need to be analysed separately. Furthermore, premenopausal and postmenopausal women may behave in a different fashion. The power of our study to refute the possibility that premenopausal women later developing RA would have lowered DHEAS levels as suggested by Masi et $a l^{25}$ is not very strong. On the other hand, it must be considered that the above finding by Masi et al was based on 11 cases and there was no prior hypothesis that there would be a difference particularly in premenopausal women.

Different studies have shown a wide variation in testosterone and DHEAS levels. ${ }^{72}$ Variation in laboratory methods obviously accounts for most of this difference, yet some differences may occur among populations. ${ }^{30}$ Accordingly, the possibility cannot be wholly excluded that low concentration is a predictor of disease in one population but not in another.

A problem in virtually all epidemiological studies dealing with circulating steroid hormones as predictors of disease is that they have been based on single point estimations. Fairly good evidence is available from short-term studies that intra-individual variability in hormone concentrations is much smaller than interindividual variation ${ }^{33}$; however, the correlation coefficients among specimens taken from the same person tend to decline with time. ${ }^{34}$ To our knowledge no studies have been published on the persistence of steroid hormone concentration over periods comparable to those used for the prediction of hormone concentrations for disease. Yet significant genetic control of testosterone ${ }^{35}$ and DHEAS ${ }^{36}$ concentrations seems to exist in humans, favouring the view that single point estimations can be used as predictors of disease occur- rence. A direct study along these lines is in progress.

In addition to the equivocal observations concerning circulating sex steroids, there is indirect evidence supporting the view that low androgen concentrations are involved in the aetiopathogenesis of RA. ${ }^{37}$ In particular, attention has been paid on sex ratios of offspring of patients with RA. It has been hypothesised that the sexes of mammalian (including human) offspring are partially controlled by parental hormone concentrations at the time of conception. ${ }^{38}$ Some evidence exists that women with RA are more likely to have daughters rather than sons. ${ }^{24}{ }^{39}$ If androgen-anabolic hormones indeed play a part, it may well be that sex hormone receptors are the key. ${ }^{19}$

Our data for now do not favour the view that circulating concentrations of the above hormones are strongly related to RA risk. Entirely different approaches are probably needed to further elucidate the putative endocrinological basis of RA.

1 Masi AT. Incidence of rheumatoid arthritis: do the observed age-sex interaction patterns support a role of androgenicanabolic steroid deficiency in its pathogenesis? $\mathrm{Br} \mathrm{J}$ Rheumatol 1994;33:697-701.

2 Brennan P, Silman A. Why the gender difference in susceptibility to rheumatoid arthritis? Ann Rheum Dis 1995;54: 694-95.

3 Silman AJ, Hochberg MC. Epidemiology of rheumatoid arthritis. Oxford: Oxford University Press, 1993.

4 Heliövaara M, Aho K, Reunanen A, Knekt P, Aromaa A. Parity and risk of rheumatoid arthritis in Finnish women. Parity and risk of rheumatoid ar

5 Pladeval-Vila M, Delclos GL, Varas C, Guyer H, BruguésTarradelas J, Angladasa-Arisa A. Controversy of oral contraceptives and risk of rheumatoid arthritis: metaanalysis of conflicting studies and review of conflicting meta-analyses with special emphasis to heterogeneity. Am J Epidemiol 1996;144:1-14.

6 Ebeling P, Koivisto VA. Physiological importance of dehydroepiandrosterone. Lancet 1994;343:1479-81.

7 Masi AT. Sex hormones and rheumatoid arthritis: cause of effect relationship in a complex pathophysiology? Clin Exp Rheumatol 1995;13:227-40.

8 Cutulo M, Balleari E, Accardo S, Samanta E, Cimmino MA, Giusti M, et al. Preliminary results of serum androgen level testing in men with rheumatoid arthritis. Arthritis Rheum 1984;27:958-9.

9 Cutulo M, Balleari E, Giusti M, Monachesi M, Accardo S. Sex hormone status of male patients with rheumatoid arthritis: evidence of low serum concentrations of testosterone at baseline and after human chorionic gonadotropin one at baseline and after human chorionic gon

10 Gordon D, Beastall GH, Thomson JA, Sturrock RD. Androgenic status and sexual function in males with rheumatoid arthritis and ankylosing spondylitis. Q J Med 1986; 60:671-9.

11 Spector TD, Ollier W, Perry LA, Silman AJ, Thompson PW, Edwards A. Free and serum testosterone levels in 276 males: a comparative study of rheumatoid arthritis, ankylosing spondylitis and healthy controls. Clin Rheumatol 1989;8:37-41.

12 Spector TD, Perry LA, Tubb G, Silman AJ, Huskisson EC. Low free testosterone levels in rheumatoid arthritis. Ann Rheum Dis 1988;47:65-8.

13 Dougados M, Nahoul K, Benhamou L, Amor B. Androgen plasma levels in female rheumatoid arthritis patients. plasma levels in female rheumathritis Rheum 1983;26:935-6.

14 Cutulo M, Balleari E, Giusti M, Monachesi M, Accardo S. Sex hormone status in women suffering from rheumatoid Sex hormone status in women suffering

15 Fehér KG, Fehér T, Merétey K. Interrelationship between immunological and steroid hormone parameters in rheumatoid arthritis. Exp Clin Endocrinol 1986;87:38-42.

16 Spector TD, Perry LA, Tubb G, Huskisson EC. Androgen status of females with RA. Br J Rheumatol 1987;26:31618.

17 Sambrook PN, Eisman JA, Champion GD, Pocock NA. Sex hormone status and osteoporosis in postmenopausal women with rheumatoid arthritis. Arthritis Rheum 1988; 31:973-8.

18 Arnalich F, Benito-Urbina S, Gonzales Cancedo P, de Miguel E, Gijon Banos J. Elévations des androgenes plasmatiques chez les femmes menopausées atteintes de polyarthrite rhumatoide. Revue du Rhumatisme et des polyarthrite rhumatoide. Revue du Rhumatis
Maladies Osteo-Articulaires 1990;57:509-12.

19 Deighton CM, Watson MJ, Walker DJ. Sex hormones in postmenopausal HLA-identical rheumatoid arthritis discordant sibling pairs. J Rheumatol 1992;19:1663-7. 
20 Hall GM, Perry LA, Spector TD. Depressed levels of dehydroepiandrosterone sulphate in postmenopausal women with rheumatoid arthritis but no relation with axial bone density. Ann Rheum Dis 1993;52:211-14.

21 Cutulo M, Accardo S, Balleari E, Sulli A, Seriolo B, Giusti $M$. Androgen status in postmenopausal patients with rheumatoid arthritis. J Rheumatol 1993;20:2163-4.

22 Gordon D, Beastall GH, Thompson JA, Sturrock RD. Prolonged hypogonadism in male patients with rheumatoid arthritis during flares of disease activity. Br J Rheumatol 1988;27:440-4

23 Ollier W, Spector T, Silman A, Perry L, Ord J, Thomson W, et al. Are certain HLA haplotypes responsible for low testosterone levels in males? Dis Markers 1989;7:139-43.

24 Deighton CM, Watson M, Walker DJ. RA sex ratios, HLADR, and testosterone. Ann Rheum Dis 1993;52:244.

25 Masi AT, Chatterton RT, Comstock GW, Malamet RL, Hochberg MC. Decreased serum dehydroepiandrosterone sulphate (DHAS) levels before onset of RA in younger premenopausal women: a controlled prospective study. Arthrimenopausal women: a controlled pros

26 Aho K, Heliövaara M, Knekt P, Reunanen A, Aromaa A, Kurki P, et al. Serum immunoglobulins and the risk of rheumatoid arthritis. Ann Rheum Dis 1997;56:351-6.

27 Breslow NE, Day NE. Statistical methods in cancer research. Vol 1. The analysis of case-control studies. Lyon: JACR Scientific Publications 32, 1980:248-79.

28 Alexandersen P, Haarboo J, Christiansen C. The relationship of natural androgens to coronary heart disease in males: a review. Atherosclerosis 1996;125:1-13.

29 Nomura AMY, Kolonel LN. Prostate cancer: A current perspective. Epidemiol Rev 1991;13:200-27.
30 Berstein L, Ross RK. Endogenous hormones and breast cancer risk. Epidemiol Rev 1993;15:48-65.

31 Kaarela K, Alekberova Z, Lehtinen K, Puolakka K, Koskimies S, Nassonova V, et al. Seronegative rheumatoid arthritis: a clinical study with HLA typing. J Rheumatol 1990;17:1125-9.

32 LaCroix AZ, Yano K, Reed DM. Dehydroepiandrosterone sulphate, incidence of myocardial infarction, and extent of atherosclerosis in men. Circulation 1992;86:1529-35.

33 Couwenbergs C, Knussman R, Christiansen K. Comparisons of the intra- and interindividual variability in sex hormone levels of men. Ann Hum Biol 1986;13:63-72.

34 Dai WS, Kuller LH, LaPorte RE, Gutai JP, Falvo-Gerard L, Caggiula A. The epidemiology of plasma testosterone levels in middle-aged men. Am J Epidemiol 1981;114:80416.

35 Meikle AW, Bishop DT, Stringham JD, West DW. Quantitating genetic and nongenetic factors that determine plasma sex steroid variation in normal male twins. Metabolism 1986;35:1090-5.

36 Rotter JI, Wong L, Lifrank ET, Parker LN. A genetic component to the variation of dehydroepiandrosterone sulphate. Metabolism 1985;34:731-6.

37 James WH. Rheumatoid arthritis, the contraceptive pill, and androgens. Ann Rheum Dis 1993;52:470-4

38 James WH. The hypothesized control of mammalian sex ratio at birth - a second update. J Theor Biol 1992;155: 121-8.

39 Brennan P, Silman A. Role of androgens in the aetiology of rheumatoid arthritis. Ann Rheum Dis 1996;55:404. 